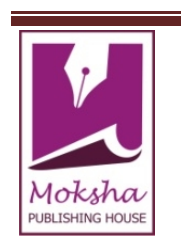

INTERNATIONAL RESEARCH JOURNAL OF PHARMACY

www.irjponline.com

ISSN $2230-8407$

Research Article

\title{
ISOCRATIC SEPARATION OF FOUR BETA BLOCKERS WITH AMLODIPINE BY C 18 RP-HPLC: APPLICATION TO AMLODIPINE DETERMINATION IN PHARMACEUTICAL DOSAGE FORMS
}

\author{
Panchumarthy Ravisankar*1,2, Garikapati Devala Rao ${ }^{3}$ \\ ${ }^{* 1}$ Department of Pharmaceutical Analysis and Quality Assurance, Vignan Pharmacy College, Vadlamudi, Guntur, A.P., India \\ ${ }^{2}$ Faculty of Science, Sri Chandrasekharendra Saraswathi Viswa Maha Vidyalaya (SCSVMV University), Enathur, Tamilnadu, \\ India \\ ${ }^{3}$ Department of Pharmaceutical Analysis, KVSR Siddhartha College of Pharmaceutical Sciences, Vijayawada, A.P., India \\ *Corresponding Author Email: banuman35@gmail.com
}

Article Received on: 17/03/13 Revised on: 09/04/13 Approved for publication: 18/05/13

DOI: $10.7897 / 2230-8407.04620$

IRJP is an official publication of Moksha Publishing House. Website: www.mokshaph.com

(C) All rights reserved.

\section{ABSTRACT}

This method described for the successful separation of a beta blockers with amlodipine by RP-HPLC on a $\mathrm{C}_{18}$ column with UV detection. One of the key goals of High Performance Liquid Chromatography technique is to achieve a consistent and reproducible separation. A simple, precise, selective and sensitive HPLC method was developed and validated for determination of five anti-hypertensive agents, atenolol hydrochloride, metoprolol succinate, propranolol hydrochloride, amlodipine besylate and nebivolol hydrochloride with application to estimation of amlodipine besylate. RP-HPLC method was developed by using Welchrom $\mathrm{C}_{18}$ column (4.6 mm i.d. X 250mm, $\left.5 \mu \mathrm{m}\right)$, Shimadzu LC-20AT ProminenceLiquid Chromatograph. The mobile phase composed of $10 \mathrm{mM}$ Phosphate buffer ( $\mathrm{pH} 3.0$, adjusted with triethylamine): acetonitrile (50:50, v/v). The flow rate was set to $1.0 \mathrm{ml} / \mathrm{min}$ with the responses measured at $235 \mathrm{~nm}$ using Shimadzu SPD-20A Prominence UV-Visible detector. This method provides effective and reproducible separation of five anti-hypertensive agents less than 6 minutes. The retention times of atenolol hydrochloride, metoprolol succinate, propranolol hydrochloride, amlodipine besylate and nebivolol hydrochloride were found to be $2.310 \mathrm{~min}, 2.830 \mathrm{~min}, 3.473 \mathrm{~min}, 4.260 \mathrm{~min}$ and $4.960 \mathrm{~min}$ respectively. The statistical validation of the developed method was carried out according to ICH guidelines. Amlodipine besylate was found to give linear response in the concentration range of $2-10 \mu \mathrm{g} / \mathrm{ml}$. Recovery studies were performed to ascertain the accuracy by standard addition method and average recovery was found to be $99.83-100.40 \%$. The LOD and LOQ were found to be $0.2251 \mu \mathrm{g} / \mathrm{ml}$ and $0.6823 \mu \mathrm{g} / \mathrm{ml}$ respectively. The developed method can be used for routine quality control analysis of amlodipine besylate in pharmaceutical tablet dosage form. It can also be extended for the determination of other above mentioned most commonly prescribed anti-hypertensive agents. The analysis yields a simple, rapid analysis, reduction in runtime, with excellent peak shape, high resolution as well as outstanding reproducibility.

Keywords: Isocratic RP-HPLC method, Atenolol hydrochloride, Metoprolol succinate, Propranolol hydrochloride, Amlodipine besylate, Nebivolol hydrochloride.

\section{INTRODUCTION}

Atenolol (ATEN) is a synthetic selective $\beta_{1}$ receptor antagonist, a drug belonging to the group of beta blockers (sometimes written $\beta$-blockers) used primarily in the treatment of hypertension, angina pectoris, heart failure and heart attacks. ATEN is chemically 2-[4-[2-hydroxy-3-(1methylethylamino)propoxy]phenyl]ethanamide (Figure 1a). Metoprolol (METO) is a selective $\beta_{1}$-receptor blocker used to treat high blood pressure, angina, and congestive heart failure. METO is chemically 1-(Isopropylamino)-3-[4-(2methoxyethyl)phenoxy]-2-propanol succinate (Figure 1b). Propranolol (PROP) is a synthetic $\beta$-adrenergic receptor blocking agent used to control high blood pressure, relieve symptoms of angina and treat other conditions related to the heart and blood vessels. By decreasing heart rate, blood pressure and heart's workload, this medication reduces the risks that accompany the long-term hypertension. PROP is chemically1-(1-methylethylamino)-3-(1-naphthyloxy)

Propan-2-ol (Figure 1c). Amlodipine (AMLO) is a longacting calcium channel antagonist of dihydropyridine (DHP) class is indicated for the treatment of hypertension, to lower blood pressure. Lowering blood pressure reduces the risk of fatal and nonfatal cardiovascular events, primarily strokes and myocardial infarctions. Amlodipine acts by relaxing the smooth muscle in the arterial wall, decreasing total peripheral resistance thereby reducing blood pressure. AMLO is chemically 3-ethyl-5-methyl-2-[(2-aminoethoxy) methyl]-4-(2-chlorophenyl)-6-methyl-3, 5-pyridine dicarboxylate, monobenzenesulphonate (Figure 1d). Nebivolol (NEBI) is prescribed for the treatment of high blood pressure. It belongs to a class of medicines called beta blockers that can help decrease heart rate and both systolic and diastolic blood pressure. It has a nitric oxide potentiating, vasodilatory effect and is used in treatment of hypertension. Nebivolol lowers blood pressure by reducing peripheral vascular resistance and increases stroke volume with preservation of cardiac output. The medication, which is generally taken once a day, can be used alone or in combination with other blood pressure medications. NEBI is chemically1-(6-fluorochroman-2-yl)-\{[2-(6-fluorochroman2-yl)-2-hydroxy ethyl] amino $\}$ ethanol (Figure 1e). Literature survey reveals that for the determination of above said five anti-hypertensive agents in biological fluids like plasma, blood, urine and pharmaceutical dosage forms by spectrophotometry $^{1-4}$, spectrofluorimetry ${ }^{5}$, TLC $^{6-7}$, HPTLC $^{8-9}$, High Performance Liquid Chromatography (RP-HPLC) with $\mathrm{UV}$ detection ${ }^{10-21}$, fluorimetric detection ${ }^{22}$, ion-pair HPLC $^{23}$, RP-UPLC $^{24}$ and Liquid Chromatography-Mass Spectrometry $^{25-26}$. As a matter of fact there is a need for the development of a novel, simple, rapid, efficient RP-HPLC analytical method with reproducibility for determination of AMLO in bulk and pharmaceutical dosage forms. When developing a new method one of the most salient goal for the any chromatographer is to accomplish a consistent reproducible separation. The selection of a highly reproducible HPLC column and decorous method is essential if this goal is to be achieved. Literature survey revealed that few chromatographic and spectrophotometric methods are described for separation and determination of ATEN, METO, PROP, AMLO and NEBI individually. However no RPHPLC method is reported till date for simultaneous separation and subsequent estimation of these drugs in bulk 
and pharmaceutical dosage forms. Thus the present study illustrates separation and analysis of a mix of five analytes from the anti-hypertensive family. The separation yields excellent peak shape and resolution in short runtimes as well as outstanding reproducibility. The established method was validated with respect to specificity, linearity, precision, accuracy, robustness, LOD and LOQ according to ICH guidelines $^{27}$.

\section{MATERIALS AND METHODS}

\section{Chemicals and Reagents}

The reference standards of ATEN, METO, PROP, AMLO, NEBI were kindly gifted by Hetero Drugs Ltd., Hyderabad, Andhra Pradesh, India. All the chemicals were analytical grade. Potassium dihydrogen orthophosphate, acetonitrile (HPLC grade) and triethylamine (HPLC grade) are from Merck Pharmaceuticals Private Ltd., Mumbai, India. OPhosphoric acid of HPLC grade purchased from Merck Specialties Private Ltd., Mumbai, India. Commercial tablets of AMLO formulation was procured from local market. STAMLO tablets containing AMLO $(5 \mathrm{mg})$ are manufactured by Dr.Reddy's Laboratories Ltd., Hyderabad, India.

\section{Instruments}

Quantitative HPLC was performed on a isocratic high performance liquid chromatograph (Shimadzu LC-20AT Prominence Liquid Chromatograph) with a LC-20AT VP pump, manual injector with loop volume of $20 \mu$ (Rheodyne), programmable variable wavelength Shimadzu SPD-20A Prominence UV-Vis detector and Welchrom $\mathrm{C}_{18}$ column (4.6mm i.d. X $250 \mathrm{~mm}, 5 \mu \mathrm{m}$ particle size). The HPLC data acquisition system was equipped with "Spinchrom" software. In addition shimadzu electronic balance (TX 223L), digital pH meter (Systronics model 802), an ultrasonic bath (POWER SONIC, model UB 405), UV-Visible Spectrophotometer (Systronics model 2203) were used in this study.

\section{Chromatographic conditions}

AMLO was analyzed by various reversed phase columns like $\mathrm{C}_{8}$ and $\mathrm{C}_{18}$ columns. $\mathrm{C}_{18}$ column with dimensions $4.6 \mathrm{~mm}$ i.d. X $250 \mathrm{~mm}, 5 \mu \mathrm{m}$ particle size was selected. Various combinations of acetonitrile and phosphate buffer with triethylamine were tested. The mixture of $10 \mathrm{mM}$ Phosphate buffer solution adjusted to $\mathrm{pH} 3.0$ with triethylamine and Acetonitrile in ratio of 50:50, v/v was selected as mobile phase and UV detection wavelength was $235 \mathrm{~nm}$ with a flow rate of $1 \mathrm{ml} / \mathrm{min}$. Injection volume was $20 \mu \mathrm{l}$, with ambient temperature, run time was $6 \mathrm{~min}$. and retention time was $4.293 \mathrm{~min}$.

\section{Preparation of solutions and Reagents Mobile phase}

Mobile phase was freshly prepared by mixing $10 \mathrm{mM}$ Phosphate buffer with acetonitrile in the ratio of 50:50, v/v respectively. $10 \mathrm{mM}$ Phosphate buffer was prepared by dissolving $6.056 \mathrm{~g}$ of potassium dihydrogen orthophosphate in $445 \mathrm{ml}$ of HPLC grade water and adding $55 \mathrm{ml}$ of $0.1 \mathrm{M}$ phosphoric acid and adjusted to $\mathrm{pH} 3.0$ with triethylamine. The mobile phase prepared was filtered through $0.45 \mu \mathrm{m}$ nylon membrane filter and degassed by sonication.

\section{Stock and Working Standard Solutions}

An accurately weighed quantity of AMLO was dissolved in mobile phase to obtain a stock standard solution of AMLO with concentration of $100 \mu \mathrm{g} / \mathrm{ml}$. Prepare five working standard solutions for calibration by adding defined volumes of the stock standard solution and diluting with mobile phase. The concentrations of AMLO obtained for calibration are 2.0, $4.0,6.0,8.0,10.0 \mu \mathrm{g} / \mathrm{ml}$, respectively. Similarly $10 \mu \mathrm{g} / \mathrm{ml}$ of each standard Anti-Hypertensive agent was prepared from $500 \mu \mathrm{g} / \mathrm{ml}$ stock standard solutions of ATEN, METO, PROP and NEBI respectively into each $10 \mathrm{ml}$ volumetric flask.

\section{Sample preparation}

The sample was prepared from tablets of AMLO (STAMLO). Five tablets of AMLO were weighed and finely powdered. An equivalent of $5 \mathrm{mg}$ of this powder was weighed and transferred to a $100-\mathrm{ml}$ volumetric flask. $75 \mathrm{ml}$ of mobile phase was added to the flask and this solution was sonicated for 15 minutes, with stirring at 5-minute intervals. Mobile phase was added to make-up the volume to $100 \mathrm{ml}$ and this solution was passed through a $0.45 \mu \mathrm{m}$ porous glass microfiber membrane filter. This solution was further suitably diluted for chromatography.

\section{Selection of detection wavelength}

The overlain UV spectra of various diluted solutions of ATEN, METO, PROP, AMLO and NEBI in mobile phase were recorded using UV spectrophotometer. The isobestic point of maximum absorbance was observed at $235 \mathrm{~nm}$. This wavelength was used for detection of AMLO and other antihypertensive agents.

\section{Calibration curve for Amlodipine besylate}

The chromatograms were recorded for each calibration standard solutions $(2,4,6,8,10 \mu \mathrm{g} / \mathrm{ml})$ by injecting $20 \mu \mathrm{l}$ of calibration standard solutions into fixed loop system. Calibration curves were constructed by plotting concentration of AMLO on X-axis and peak areas of standard AMLO on Yaxis and regression equations were computed for AMLO.

\section{Validation of the Proposed Method}

The developed method was validated based on the International Conference on Harmonization (ICH) guidelines. The method validation parameters checked for system suitability, specificity, linearity, precision, accuracy, robustness and system suitability, limit of detection (LOD) and limit of quantitation (LOQ).

\section{System suitability}

System suitability test wascarried out on freshly prepared AMLO standard solution, which was used for the evaluation of the system suitability parameters such as retention time, peak tailing, number of theoretical plates, LOD and LOQ. At first the HPLC system was stabilized for 40min. One blank followed by six replicates of a single calibration standard solution of AMLO was injected to check the system suitability.

\section{Specificity}

The specificity of the method was performed by comparing the chromatograms of blank, standard and sample in triplicate. The effect of wide range of excipients and other additives usually present in the formulations of AMLO in the determinations under optimum conditions was investigated. The common excipients such as lactose anhydrous, microcrystalline cellulose, purified talc and magnesium stearate have been added to the placebo solution and injected 
and tested. The chromatogram for placebo indicating the specificity of developed method is presented in Figure 2.

Table 1: Optimized Chromatographic Conditions and System Suitability Parameters of Proposed RP-HPLC Method for Amlodipine Besylate

\begin{tabular}{|c|c|}
\hline Parameter & Chromatographic conditions \\
\hline Instrument & SHIMADZU LC-20AT prominence liquid chromatograph \\
\hline Column & $\begin{array}{c}\text { WELCHROM C }{ }_{18} \text { Column } \\
(4.6 \mathrm{~mm} \text { i.d. X } 250 \mathrm{~mm}, 5 \mu \mathrm{m} \text { particle size })\end{array}$ \\
\hline Detector & SHIMADZU SPD-20A prominence UV-Vis detector \\
\hline Diluents & 10mM Phosphate Buffer(pH3.0) : Acetonitrile (50:50, v/v) \\
\hline Mobile phase & $10 \mathrm{mM}$ Phosphate Buffer $(\mathrm{pH} 3.0):$ Acetonitrile $(50: 50, \mathrm{v} / \mathrm{v})$ \\
\hline Flow rate & $1 \mathrm{ml} / \mathrm{min}$. \\
\hline Detection wave length & $\mathrm{UV}$ at $235 \mathrm{~nm}$. \\
\hline Run time & 6 minutes \\
\hline Column back pressure & $128-130 \mathrm{kgf}$ \\
\hline Temperature & Ambient temperature $\left(25^{\circ} \mathrm{C}\right)$ \\
\hline Volume of injection loop & $20 \mu 1$ \\
\hline Retention time $\left(t_{R}\right)$ & $4.293 \mathrm{~min}$ \\
\hline Theoretical plates[th.pl] (Efficiency) & 12,238 \\
\hline Theoretical plates per meter [t.p/m] & 244,751 \\
\hline Tailing factor (asymmetry factor) & 1.062 \\
\hline
\end{tabular}

Table 2: Linear Regression Data of the Proposed HPLC Method of Amlodipine Besylate

\begin{tabular}{|c|c|}
\hline Parameter & Method \\
\hline Detection wavelength $\left(\lambda_{\max }\right)$ & UV at $235 \mathrm{~nm}$ \\
\hline Linearity range $(\mu \mathrm{g} / \mathrm{ml})$ & $2-10 \mu \mathrm{g} / \mathrm{ml}$ \\
\hline Regression equation $(\mathrm{Y}=\mathrm{a}+\mathrm{bX})$ & $\mathrm{Y}=6.7286+103.3 \mathrm{X}$ \\
\hline Slope $(\mathrm{b})$ & 103.3 \\
\hline Intercept $(\mathrm{a})$ & 6.7286 \\
\hline Standard error of slope $\left(\mathrm{S}_{\mathrm{b}}\right)$ & 1.164045488 \\
\hline Standard error of intercept $\left(\mathrm{S}_{\mathrm{a}}\right)$ & 7.048645468 \\
\hline Standard error of estimation $\left(\mathrm{S}_{\mathrm{e}}\right)$ & 9.739103289 \\
\hline Regression coefficient $\left(\mathrm{R}^{2}\right)$ & 0.9995 \\
\hline \% Relative standard deviation* i.e., Coefficient of variation $(\mathrm{CV})$ & 0.994199868 \\
\hline Percentage range of errors* $($ Confidence limits) & \\
0.005 significance level & 1.237245235 \\
0.001 significance level & 1.940708374 \\
\hline
\end{tabular}

Table 3: Calibration Data of the Proposed HPLC Method for Estimation of Amlodipine Besylate

\begin{tabular}{|c|c|c|}
\hline Concentration, $\boldsymbol{\mu g} / \mathbf{m l}$ & Retention Time, $\left(\mathbf{t}_{\mathbf{r}}\right) \mathbf{m i n}$. & Peak Area, mv.s. \\
\hline 0 & - & 0 \\
\hline 2 & 4.237 & 214.368 \\
\hline 4 & 4.237 & 422.710 \\
\hline 6 & 4.243 & 631.577 \\
\hline 8 & 4.233 & 844.312 \\
\hline 10 & 4.293 & 1026.509 \\
\hline
\end{tabular}

Table 4: Assay Results of Amlodipine Besylate Formulation

\begin{tabular}{|c|c|c|c|}
\hline Formulations & Labelled amount & Amount found & \% Assay \pm SD $^{*}$ \\
\hline STAMLO (Dr. Reddy's Laboratories Ltd., Hyderabad) & $5 \mathrm{mg}$ & $5.018 \mathrm{mg}$ & $100.377 \pm 0.998 \%$ \\
\hline
\end{tabular}

Table 5: Specificity Study

\begin{tabular}{|c|c|}
\hline Name of the solution & Retention time, $\left(\mathbf{t}_{\mathbf{R}}\right)$ min. \\
\hline Mobile phase & No peaks \\
\hline Placebo & No peaks \\
\hline Amlodipine besylate, $10 \mu \mathrm{g} / \mathrm{ml}$ & 4.293 min. \\
\hline
\end{tabular}

Table 6: Results of Precision Study (Intra-Day)

\begin{tabular}{|c|c|c|c|c|}
\hline Sample & Concentration $(\boldsymbol{\mu g} / \mathbf{m l})$ & Injection no. & Peak area $(\mathbf{m V} . \mathbf{s})$ & \% RSD \\
\hline Amlodipine besylate & \multirow{3}{*}{5} & 1 & 528.261 & \multirow{3}{*}{0.295277} \\
\cline { 3 - 4 } & & 2 & 526.307 & \\
\cline { 3 - 4 } & & 3 & 524.181 & \\
\cline { 3 - 4 } & & 4 & 525.819 & \\
\cline { 3 - 4 } & & 5 & 525.04 & \\
\cline { 3 - 4 } & & 6 & 527.592 & \\
\hline
\end{tabular}


Table 7: Results of Precision Study (Inter-Day)

\begin{tabular}{|c|c|c|c|c|}
\hline Sample & Concentration $(\boldsymbol{\mu g} / \mathbf{m l})$ & Injection no. & Peak area $(\mathbf{m V} \mathbf{s})$ & \% RSD \\
\hline Amlodipine besylate & \multirow{3}{*}{5} & 1 & 528.86 & 0.587824 \\
\cline { 3 - 4 } & & 2 & 526.52 & \\
\cline { 3 - 4 } & & 3 & 521.92 \\
\cline { 3 - 4 } & & 4 & 526.643 \\
\cline { 3 - 4 } & & 5 & 521.405 \\
\cline { 3 - 4 } & & 6 & 522.863 & \\
\hline
\end{tabular}

Table 8: Recovery Data of the Proposed Amlodipine Besylate by RP-HPLC Method

\begin{tabular}{|c|c|c|c|c|c|}
\hline Recovery level & Amount added (mg) & Total amount (mg) & Total Amount found (mg) & Mean \% Recovery \pm SD* & $\%$ RSD $^{\#}$ \\
\hline \multirow[t]{3}{*}{$80 \%$} & \multirow[t]{3}{*}{4} & \multirow[t]{3}{*}{9} & 8.98 & \multirow[t]{3}{*}{$99.833 \pm 1.040$} & \multirow[t]{3}{*}{1.042} \\
\hline & & & 8.96 & & \\
\hline & & & 9.04 & & \\
\hline \multirow[t]{3}{*}{$100 \%$} & \multirow[t]{3}{*}{5} & \multirow[t]{3}{*}{10} & 10.02 & \multirow[t]{3}{*}{$100.400 \pm 0.800$} & \multirow[t]{3}{*}{0.796} \\
\hline & & & 10.06 & & \\
\hline & & & 9.98 & & \\
\hline \multirow[t]{3}{*}{$120 \%$} & \multirow[t]{3}{*}{6} & \multirow[t]{3}{*}{11} & 10.96 & \multirow[t]{3}{*}{$99.944 \pm 0.535$} & \multirow[t]{3}{*}{0.536} \\
\hline & & & 11.01 & & \\
\hline & & & 11.02 & & \\
\hline
\end{tabular}

Table 9: Robustness Results of Amlodipine Besylate

\begin{tabular}{|c|c|c|c|c|c|c|}
\hline Parameter $^{\mathrm{a}}$ & Optimized & Used & Peak area & Retention time $\left(t_{R}\right), \min$ & Plate count & Peak asymmetry \\
\hline \multirow{3}{*}{$\begin{array}{c}\text { Flow rate } \\
( \pm 0.2 \mathrm{ml} / \mathrm{min})\end{array}$} & \multirow{3}{*}{$\begin{array}{c}1.0 \\
\mathrm{ml} / \mathrm{min}\end{array}$} & $0.8 \mathrm{ml} / \mathrm{min}$ & 1096.652 & 4.686 & 12434 & 1.130 \\
\hline & & $1.0 \mathrm{ml} / \mathrm{min}$ & 1026.509 & 4.293 & 12238 & 1.062 \\
\hline & & $1.2 \mathrm{ml} / \mathrm{min}$ & 992.626 & 3.983 & 12128 & 1.184 \\
\hline \multirow{3}{*}{$\begin{array}{l}\text { Detection wavelength } \\
( \pm 5 \mathrm{~nm})\end{array}$} & \multirow{3}{*}{$235 \mathrm{~nm}$} & $230 \mathrm{~nm}$ & 1012.118 & 4.290 & 12214 & 1.130 \\
\hline & & $235 \mathrm{~nm}$ & 1026.509 & 4.293 & 12238 & 1.062 \\
\hline & & $240 \mathrm{~nm}$ & 1002.524 & 4.294 & 12252 & 1.113 \\
\hline \multirow{3}{*}{$\begin{array}{l}\text { Mobile phase } \\
\text { composition } \\
( \pm 5 \%)\end{array}$} & \multirow[t]{3}{*}{$50: 50, \mathrm{v} / \mathrm{v}$} & $55: 45, \mathrm{v} / \mathrm{v}$ & 1078.478 & 4.426 & 12682 & 1.115 \\
\hline & & $50: 50, \mathrm{v} / \mathrm{v}$ & 1026.509 & 4.293 & 12238 & 1.062 \\
\hline & & $45: 55, \mathrm{v} / \mathrm{v}$ & 1042.623 & 4.024 & 11824 & 1.104 \\
\hline
\end{tabular}

Table 10: Limit of Detection (LOD) and Limit of Quantitation (LOQ)

\begin{tabular}{|c|c|}
\hline Limit of Detection (LOD) & $0.225166 \mu \mathrm{g} / \mathrm{ml}$ \\
\hline Limit of Quantitation (LOQ) & $0.682324 \mu \mathrm{g} / \mathrm{ml}$ \\
\hline
\end{tabular}

Table 11: Chromatogram Results of Proposed Combination of Five Anti-Hypertensive Agents

\begin{tabular}{|c|c|c|c|c|c|c|}
\hline Name of the Compound & Retention time $\left(t_{R}\right)$, min & Peak No. & Assymmetry $^{\#}$ & Efficiency (th.pl) & t.p $/ \mathbf{m}^{\mathbf{b}}$ & Resolution\$ \\
\hline Atenolol hydrochloride & 2.310 & 1 & 1.066 & 5497 & 109941 & - \\
\hline Metoprolol succinate & 2.830 & 2 & 1.082 & 8250 & 165010 & 4.184 \\
\hline Propranolol hydrochloride & 3.473 & 3 & 1.046 & 11371 & 227415 & 5.061 \\
\hline Amlodipine besylate & 4.260 & 4 & 1.068 & 11541 & 230826 & 5.460 \\
\hline Nebivolol hydrochloride & 4.960 & 5 & 1.184 & 13629 & 272586 & 4.272 \\
\hline
\end{tabular}

${ }^{a}$ theoretical plates, ${ }^{b}$ theoretical plates/meter, ${ }^{\#}$ acceptance criteria $<1.5,{ }^{\mathrm{s}}$ acceptance criteria $>2.0$

Table 12: Individual Chromatogram Results of Standards of Five Anti-Hypertensive Agents

\begin{tabular}{|c|c|c|c|}
\hline Name of the Compound & Retention time (t $\mathbf{R})$, min. & Assymmetry $^{\#}$ & Efficiency (theoretical plates) $^{\text {Atenolol hydrochloride }}$ \\
\hline Metoprolol succinate & 2.310 & 1.064 & 5497 \\
\hline Propranolol hydrochloride & 2.827 & 1.082 & 8231 \\
\hline Amlodipine besylate & 3.470 & 1.062 & 10423 \\
\hline Nebivolol hydrochloride & 4.293 & 1.090 & 12238 \\
\hline
\end{tabular}




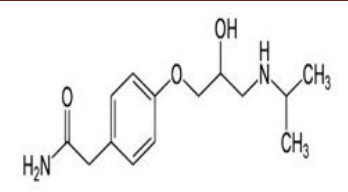

Fig. 1(a). Atenolol

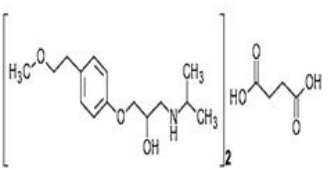

Fig. 1(b). Metoprolol succinate

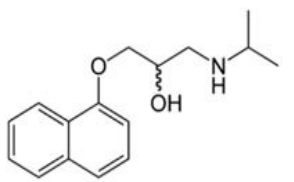

Fig. 1(c). Propranolol

\#acceptance criteria $<1.5$

Figure 1: Structures of Anti-Hypertensive drugs investigated in the present study

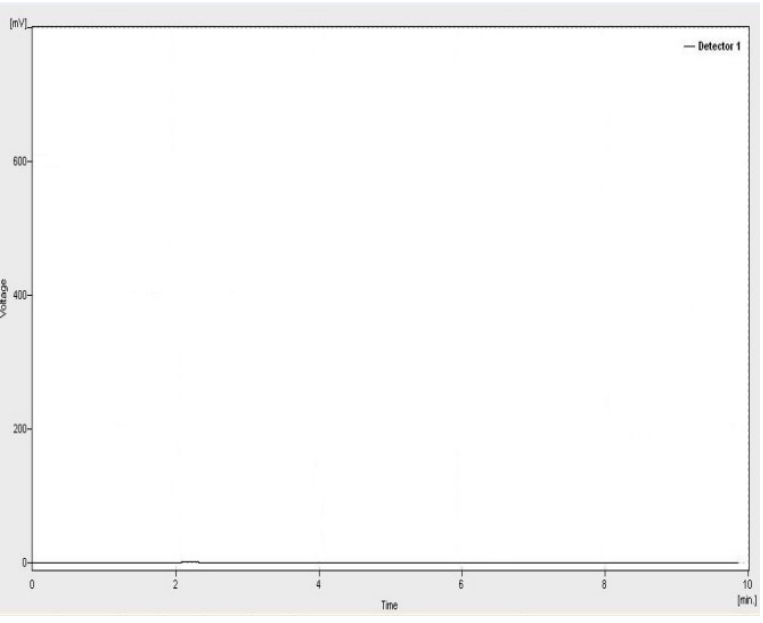

Figure 2: Chromatogram of placebo

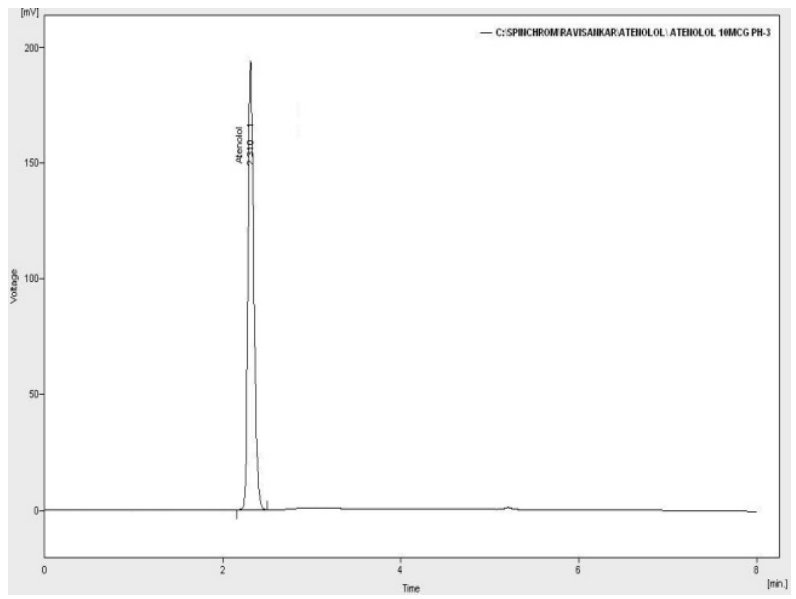

Figure 4: Standard chromatogram of Atenolol standard (10 $\mu \mathrm{g} / \mathrm{ml})$

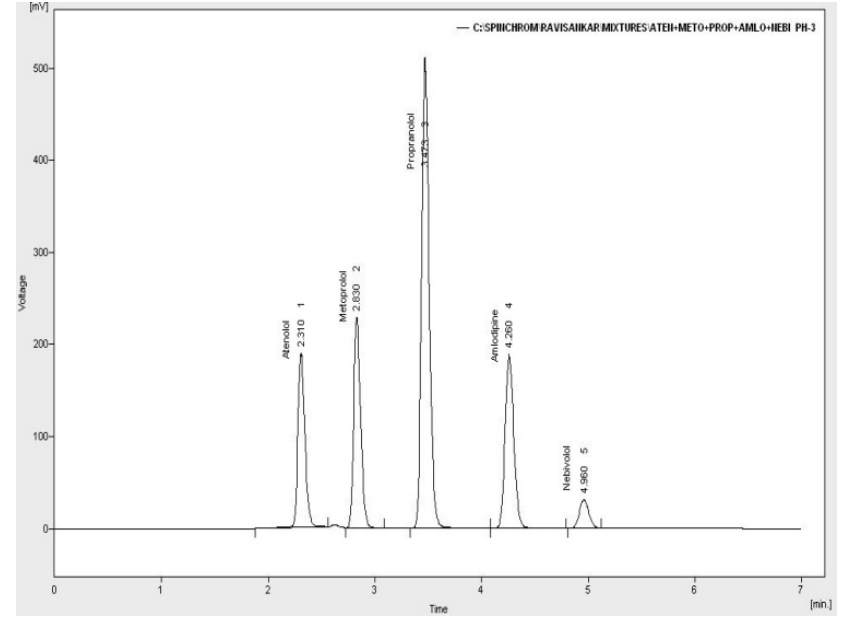

Figure 3: A typical chromatogram of Mixture of five standard AntiHypertensive agents

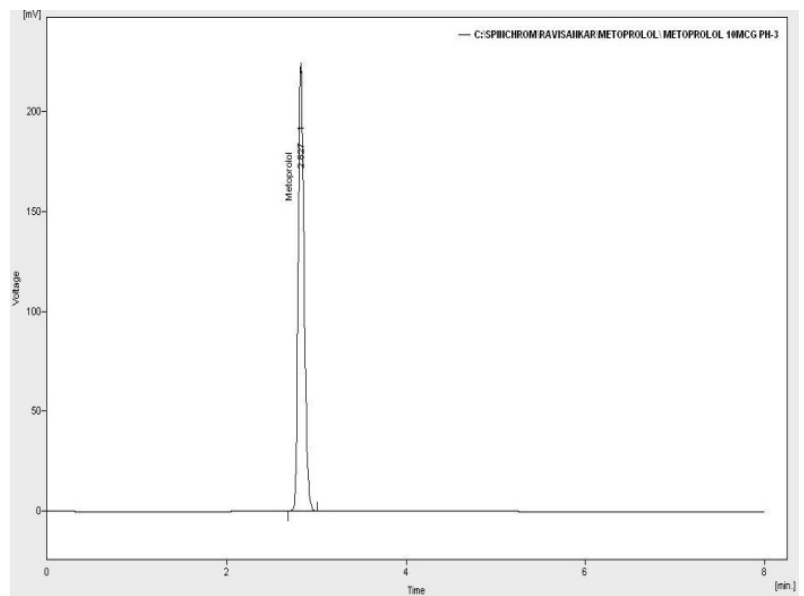

Figure 5: A typical chromatogram of Metoprolol succinate standard $(10 \mu \mathrm{g} / \mathrm{ml})$ 


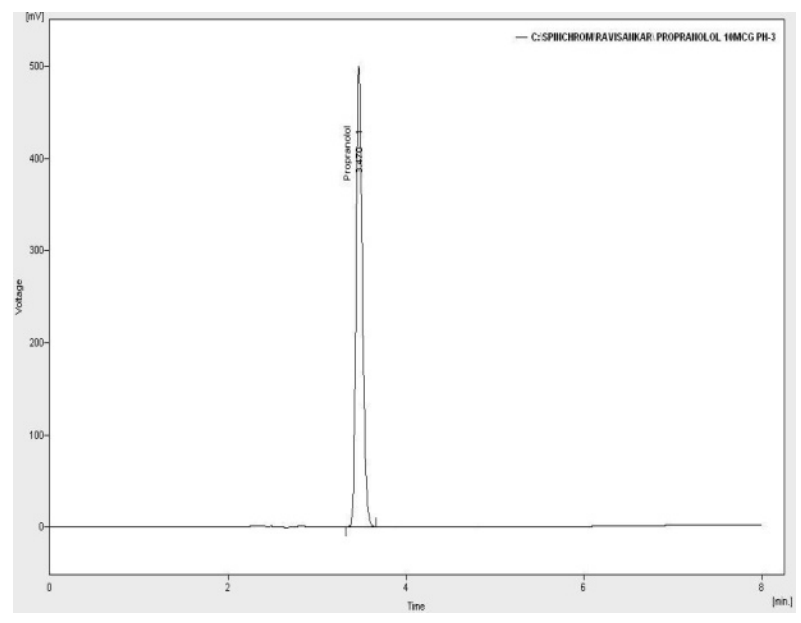

Figure 6: Standard chromatogram of Propranolol standard $(10 \mu \mathrm{g} / \mathrm{ml})$

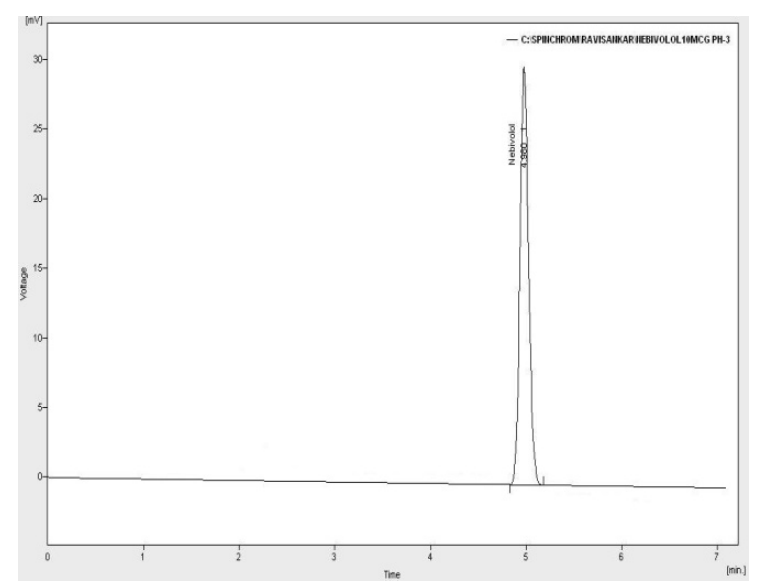

Figure 8: Standard chromatogram of Nebivolol standard $(10 \mu \mathrm{g} / \mathrm{ml})$

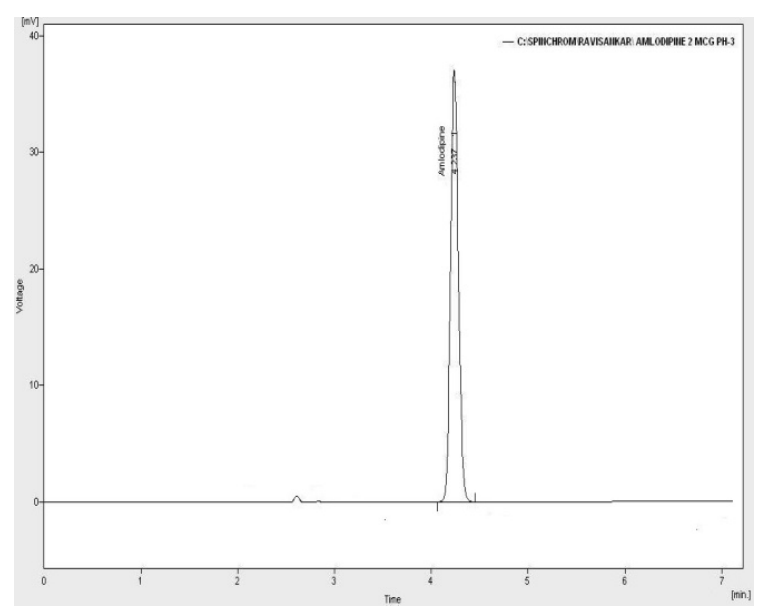

Figure 10: Standard chromatogram of Amlodipine besylate $(2 \mu \mathrm{g} / \mathrm{ml})$

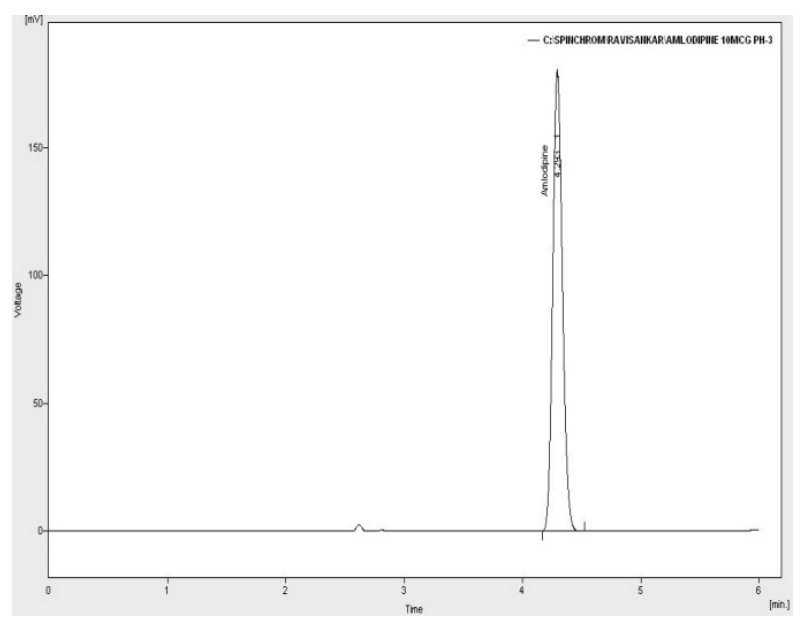

Figure 7: Standard chromatogram of Amlodipine standard $(10 \mu \mathrm{g} / \mathrm{ml})$

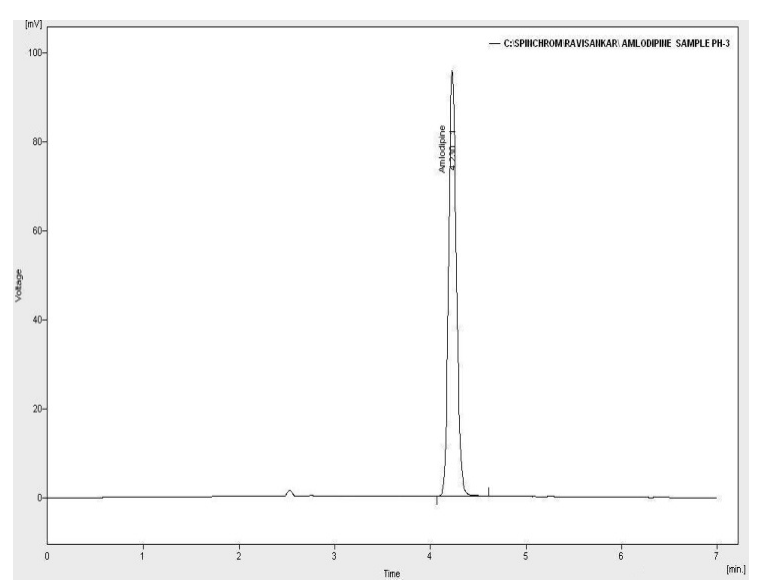

Figure 9: Chromatogram of market formulation (STAMLO) of Amlodipine besylate

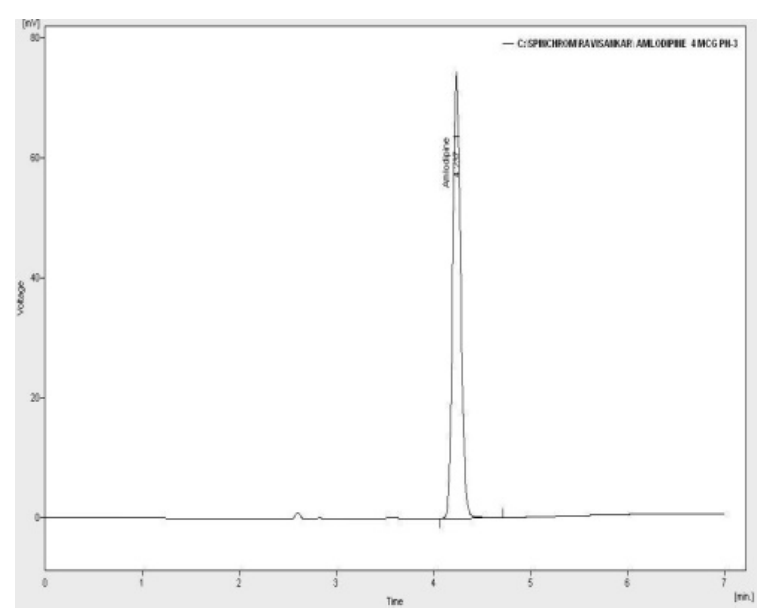

Figure 11: Standard chromatogram of Amlodipine besylate $(4 \mu \mathrm{g} / \mathrm{ml})$ 


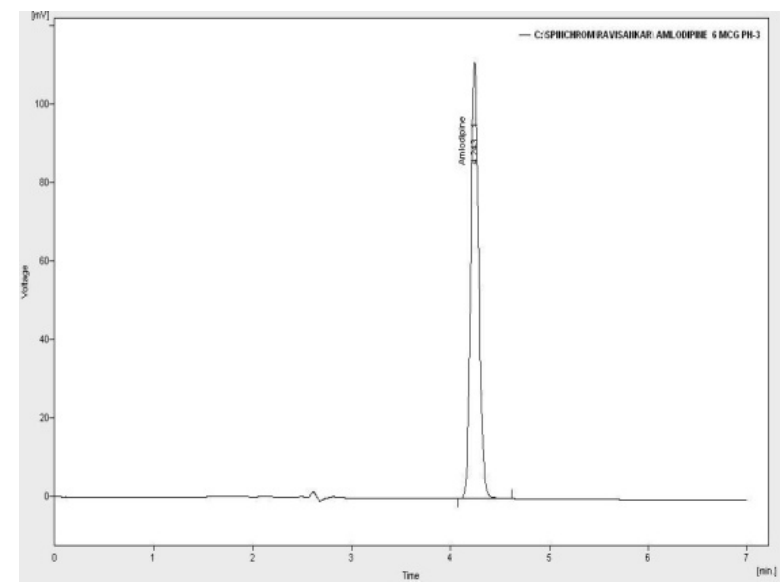

Figure 12: Standard chromatogram of Amlodipine besylate $(6 \mu \mathrm{g} / \mathrm{ml})$

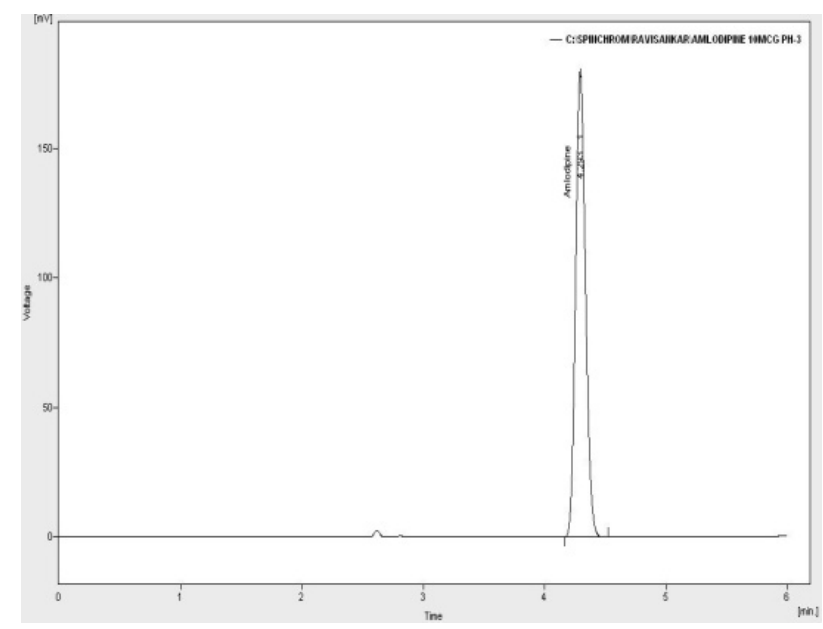

Figure 14: Standard chromatogram of Amlodipine besylate $(10 \mu \mathrm{g} / \mathrm{ml})$

\section{Linearity}

The linearity graphs for the proposed assay methods were obtained over the concentration range of $2-10 \mu \mathrm{g} / \mathrm{ml}$ of AMLO. Method of least square analysis was carried out for getting the slope, intercept and correlation coefficient, regression data values. A calibration curve was plotted between concentration and area response and statistical analysis of the calibration curve was performed.

\section{Precision}

Precision of the method was performed as Intra-day and inter-day precision. To study the precision, six-replicates of standard solution of AMLO was injected. Intra-day and interday precisionwas carried out by estimating corresponding responses 6 times on the same day and on 2 different days for the concentration of $10 \mu \mathrm{g} / \mathrm{ml}$. The percent relative standard deviation (\% RSD) was calculated which is within the acceptable criteria of not more than 2.0.

\section{Accuracy (Recovery studies)}

The accuracy of the method was determined by calculating recovery of AMLO by the standard addition method. A known amount of AMLO was added to the fixed amount of pre-analyzed tablet solution. The percent recovery was calculated by comparing the area before and after addition of

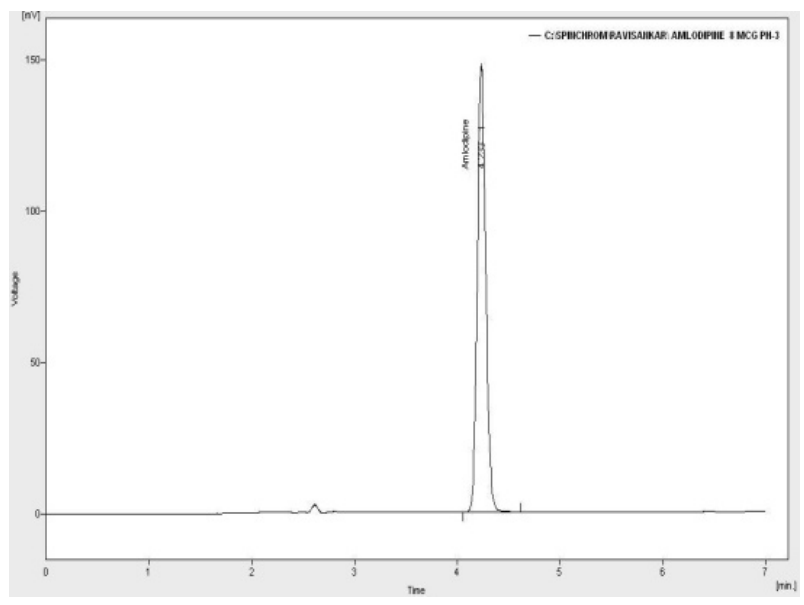

Figure 13: Standard chromatogram of Amlodipine besylate $(8 \mu \mathrm{g} / \mathrm{ml})$

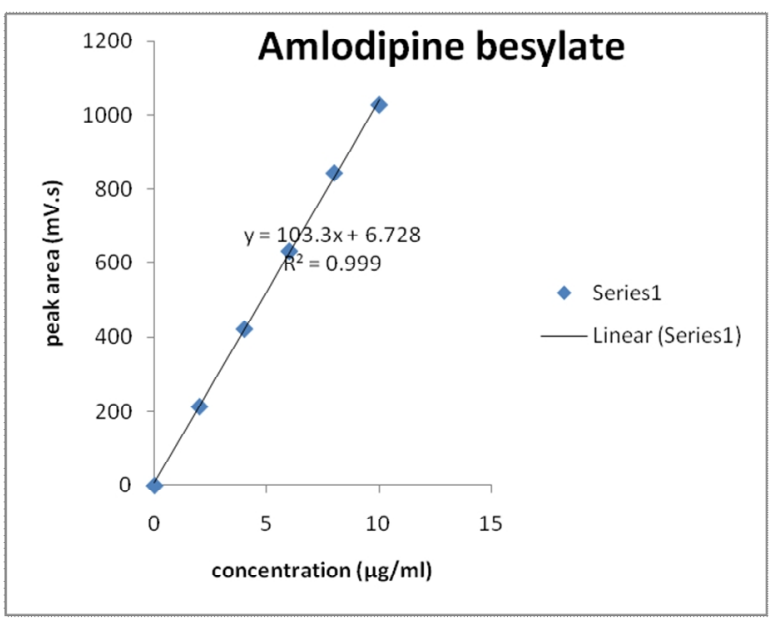

Figure 15: Calibration plot of Amlodipine Besylate

the standard drug. Recovery studies were carried out in the tablet in triplicate each in the presence of placebo. The standard addition method was performed at $80 \%, 100 \%$ and $120 \%$ level. The percent recovery and \%RSD were calculated.

\section{Robustness}

The Robustness was evaluated by the analysis of AMLO under different experimental conditions such as making small changes in flow rate $( \pm 0.2 \mathrm{ml} / \mathrm{min})$, detection wavelength $( \pm 5 \mathrm{~nm})$ and Mobile phase composition $( \pm 5 \%)$.

\section{LOD and LOQ}

Limit of Detection and Limit of Quantitation were calculated using following formula

$\mathrm{LOD}=3.3(\mathrm{SD}) / \mathrm{S}$ and $\mathrm{LOQ}=10(\mathrm{SD}) / \mathrm{S}$

Where $\mathrm{SD}=$ standard deviation of response (peak area) and $\mathrm{S}=$ slope of the calibration curve

\section{RESULTS AND DISCUSSION}

The aim of this work was to create a single method to separate five anti-hypertensive agents applicable to the determination of ATEN, METO, PROP, AMLO and NEBI and in various combinations. Preliminary experiments were performed to attain the best chromatographic conditions for 
the simultaneous determination of the drug substances. Several types of columnwere tried in order to achieveoptimal chromatographic parameters. $C_{18}$ column with a $4.6 \mathrm{~mm}$ inner diameter and $5 \mu \mathrm{m}$ particle size was chosen. Spectroscopic analysis of drugs showed that ATEN, METO, PROP, AMLO and NEBI had maximum UV absorbance $\left(\lambda_{\max }\right)$ at $237 \mathrm{~nm}$, $243 \mathrm{~nm}, 291 \mathrm{~nm}, 240 \mathrm{~nm}$ and $282 \mathrm{~nm}$ respectively. UV overlain spectra of these drugs showed that these drugs absorbed appreciably at $235 \mathrm{~nm}$, so that this wavelength was selected as the detection wave length. To optimize the mobile phase, various proportions of buffer $(\mathrm{pH} 3.0$, adjusted with triethylamine) with acetonitrile in the ratio of 50:50, v/v resulted in peaks with excellent shape and resolution.A flow rate of $1 \mathrm{ml} / \mathrm{min}$. was found to be optimum in the range of 0.6-1.4 $\mathrm{ml} / \mathrm{min}$. A representative chromatogram for simultaneous estimation of the five drugs obtained by using a fore mentioned mobile phase was presented in Figure 3. Under these conditions, the retention times of ATEN, METO, PROP, AMLO and NEBI were found to be $2.310 \mathrm{~min}$, $2.830 \mathrm{~min}, 3.473 \mathrm{~min}, 4.260 \mathrm{~min}$ and $4.960 \mathrm{~min}$ respectively. The results are listed in Table 11. The comparative evaluation of retention times and peak areas of anti-hypertensive drugs is performed by recording the individual chromatograms of these fiveanti-hypertensive drug standards. The representative individual standard chromatograms of the five anti-hypertensive drug standards are shown in Figures 4 to 8 and the results are shown in Table 1 . The mobile phase comprising of phosphate buffer $(\mathrm{pH} 3.0)$ : acetonitrile (50:50, $\mathrm{v} / \mathrm{v})$ at $1 \mathrm{ml} / \mathrm{min}$ flow rate was optimized which gave sharp peak, minimum tailing factor with short runtime for AMLO.The retention time for AMLO was 4.260 min. UV spectra of AMLO showed that the drug absorbed maximum at $235 \mathrm{~nm}$ in mobile phase, hence this wavelength was selected as the detection wavelength. System suitability parameters and optimized chromatographic conditions data is presented in Table 1. The calibration curve for AMLO was found to be linear over the range of $2-10 \mu \mathrm{g} / \mathrm{ml}$. The data of regression analysis of the calibration curve is shown in Table 2. The calibration data in Table 3 show linear peak area response for AMLO. The developed method was applied to the assay of AMLO tablets and results are shown in Table 4. The amount was between 99.3792 and $101.3757 \%$. The IP monograph for this product specifies that there should be not less than (NLT) $90.0 \%$ and not more than (NMT) $110.0 \%$ of the Active Pharmaceutical Ingredient (API) in the drug product. The assay results are indicative that formulation passes the IP criteria. The representative chromatograms of AMLO standard and sample are shown in Figure7 and Figure 9 respectively. The regression equation was $\mathrm{Y}=$ $6.728+103.3 \mathrm{X}$ with correlation coefficient was $\mathrm{R}^{2}=0.999$ which indicates this method had good linearity. The representative standard chromatograms for the calibration of AMLO are shown in Figures 10 to 14 . The calibration plot is depicted in Figure 15. The specificity of the developed method was studied for the examination of the presence of interfering components, while the comparison of chromatograms there was no interference from placebo with sample peak. They do not disturb the elution or quantification of AMLO; the well-shaped peaks were also indicative of the specificity of the method. The specificity results are presented in Table 5. Precision was studied to find out intra and inter day variations in the test methods of AMLO for the three times on the same day and different day. The intra-day and inter-day precision obtained was 0.295277 (acceptance criteria is \% RSD $(<2)$ ) which indicates that the proposed method was quite precise and reproducible and results are showed in the Table 6 and Table 7 respectively. Recovery studies of the drug was carried out for the accuracy parameter at three different concentrations levels i.e., multiple level recovery studies. A known amount of AMLO standard was added into pre-analyzed sample and subjected them to the proposed HPLC method. The percentage recovery was found to be within the limits depicted in Table 8 . Generally the mean percentage recovery of AMLO at each level was not less than $99 \%$ and not more than $101 \%$. In this case percentage recovery of AMLO was found to be in the range of 99.83 to $100.4 \%$. The method precision was done and the low \%RSD, 0.2952 indicates that the proposed method was in perfect agreement with precision. Robustness was done by making small changes in the chromatographic conditions like mobile phase flow rate, $\lambda_{\max }$, and mobile phase composition. It was found that there were no marked changes in the chromatograms. The parameters lie within the limits indicates that the method had robustness and was suitable for routine use. The Robustness results are exhibited in Table 9. The limit of detection (LOD) and limit of quantitation (LOQ) was calculated based on the standard deviation (SD) of the response and the slope $(\mathrm{S})$ of the calibration curve at levels approximating the LOD and LOQ. The limit of detection (LOD) was $0.225166 \mu \mathrm{g} / \mathrm{ml}$ and the limit of quantitation (LOQ) was $0.682324 \mu \mathrm{g} / \mathrm{ml}$ shows that this method was very sensitive. The data is summarized in Table 10.

\section{CONCLUSION}

The method successfully resolved all five beta blockers with amlodipine with a relatively short retention time. All results explicitly provide decorous resolution, excellent peak shape, gave consistent and highly reproducible results. The method overall proved to be economical, simple, rapid, precise, very sensitive, cost- effective, time saving, robust and accurate. It can be reliably used for determination of the said five antihypertensive agents in short period and even in small concentrations. By using this method one can separate all the five drugs in less than six minutes. This method was completely validated and shows extraordinary results and also free from interference of the other additives used in the formulations. Due to reduced solvent consumption, reduction in run time, simplicity of use and ease in constitution of mobile phase make this method the best choice in routine analysis of ATEN, METO, PROP, AMLO, NEBI in bulk and their pharmaceutical dosage forms. The excellent data supports this method would also be applied for the combinations of any two or three of the above said antihypertensive drugs, irrespective of their concentration levels.

\section{ACKNWOLEDGEMENT}

The authors would like to thank Hetero Labs for providing the samples of atenolol, metoprolol, propranolol, amlodipine, nebivolol. We are highly grateful to Dr.L.Rathaiah, Honorable Chairman, Vignan group of institutions, Vadlamudi, Guntur, for providing the necessary facilities to carry out this research work.

\section{REFERENCES}

1. Gupta KR, Tajne MR, Wadodkar SG. New spectrophotometric method for simultaneous determination of metoprolol tartarate and hydrochlorthiazide in tablets. Indian J Pharm Sci 2008; 70: 511-3. http:/ /dx.doi.org/10.4103/0250-474X.44606 PMid:20046783 PMCid:2792553

2. Shelke OS, Sable KS, Neharkar VS, Mathdevru BV. Development and validation of a UV spectrophotometric method for the simultaneous determination of nifedipine and atenolol in combined dosage form. Int. Res. J. Pharm 2012; 3(4): 360-4.

3. Kamila MM, Mondal N, Ghosh LK, Gupta BK. A validated UV spectrophotometric method for estimation of nebivolol hydrochloride in 
bulk and pharmaceutical formulation. Pharmazie 2007; 62(7): 486-7. PMid: 17718186

4. Thomas AB, Chavan UB, Nanda RK, Kothapalli LP, Deshpande AD, Jagdale SN, Dighe SB. Simultaneous spectrophotometric estimation of Hydrochlorothiazide, Atenolol and Losartan potassium in tablet dosage form. Hindustan Antibiot Bull 2009; 51(1-4): 33-8. PMid:21268558

5. Mohamed I Walash, Fathallah F Belal, Nahed M El-Enany, Mahmoud H El-Maghrabey. Synchronous fluorescence spectrofluorimetric method for the simultaneous determination of metoprolol and felodipine in combined pharmaceutical preparation. Chem Cent J 2011; 5: 70-9. http://dx.doi.org/10.1186/1752-153X-5-70PMid:22059735

PMCid:3223136

6. Patole SM, Khodke AS, Potale LV, Damle MC. A validated densitometric method for analysis of atorvastatin calcium and metoprolol tartarate as bulk drugs and in combined capsule dosage forms. J Young Pharmacists 2011; 3: 55-9. http://dx.doi.org/ 10.4103/0975-1483.76420 PMid:21607055 PMCid:3094561

7. Shirkhedkar AA, Bugdane PM, Surana SJ. Stability-Indicating TLCdensitometric determination of nebivolol hydrochloride in bulk and pharmaceutical dosage form. J Chromatogr Sci 2010; 48(2): 109-13. http://dx.doi.org/10.1093/chromsci/48.2.109 PMid:20109287

8. Ginoya Charmi G, Dinesh V Thakkar. Development and validation of HPTLC method for simultaneous determination of metoprolol succinate and atorvastatin calcium in a pharmaceutical dosage form. Int. Res. J. Pharm 2013; 4(2): 102-7.

9. Jain PS, Patel MK, Bari SB, Surana SJ. Development and Validation of HPTLC Method for Simultaneous Determination of Amlodipine Besylate and Metoprolol Succinate in Bulk and Tablets. Indian J Pharm Sci 2012; 74(2): 152-6. http://dx.doi.org/10.4103/0250-474X.103849 PMid:23325996 PMCid:3546332

10. Rawool ND, Venkatchalam A. Analytical method for the simultaneous estimation of hydrochlorothiazide and metoprolol tartrate using RP HPLC. Indian J Pharm Sci 2011; 73: 219-23. http://dx.doi.org/ 10.4103/0250-474X.91565 PMid:22303067 PMCid:3267308

11. Chitlange SS, Imran M, Sakarkar DM. RP-HPLC method for simultaneous estimation of amlodipine and metoprolol in tablet formulation. Asian J Pharm 2008; 2: 232-4. http://dx.doi.org/ 10.4103/0973-8398.45037

12. Patel YP, Patil S, Bhoir IC, Sundaresan M. Isocratic, simultaneous reversed-phase high-performance liquid chromatographic estimation of six drugs for combined hypertension therapy. J ChromatogrA 1998; 828(1-2): 283-6. http://dx.doi.org/10.1016/S0021-9673(98)00652-9

13. Tanikella Sai Annapurneswari, Sakinala Shilpa, Chowdavarapu Bala Tripura Sundari, Vaidya Jayathirtha Rao, Anisetti Ravinder Nath Development and validation of a RP-HPLC method for simultaneous estimation of propranolol hcl and clonazepam in bulk and pharmaceutical dosage form. Int. Res. J. Pharm 2012; 3(9): 218-22.

14. Kaila HO, Ambasana MA, Thakkar RS, Saravaia HT, Shah AK. A Stability-indicating High Performance Liquid Chromatographic Assay for the Simultaneous Determination of Atenolol and Lercanidipine Hydrochloride in Tablets. Indian J Pharm Sci 2011; 73(4): 376-80. PMid:22707819 PMCid:3374551

15. Patel DB, Mehta FA, Bhatt KK. Simultaneous Estimation of Amlodipine Besylate and Indapamide in a Pharmaceutical Formulation by a High Performance Liquid Chromatographic (RP-HPLC) Method. Sci Pharm 2012; 80(3): 581-90. http://dx.doi.org/10.3797/scipharm.1203-07 PMid:23008807 PMCid:3447622

16. Doshi Naman, Sheth Avani, Patel CN. Validated reverse phase high performance liquid chromatographic method for simultaneous estimation of olmesartanmedoximil, hydrochlorothiazide and amlodipine besylate in newly designed pharmaceutical dosage form. Int. Res. J. Pharm 2012; 3(11): 178-82

17. Shah S, Asnani A, Kawade D, Dangre S, Arora S, Yende S. Simultaneous Quantitative Analysis of Olmesartan Medoxomil and Amlodipine Besylate in Plasma by High-performance Liquid Chromatography Technique. J Young Pharm 2012; 4(2): 88-94. http:/ /dx.doi.org/10.4103/0975-1483.96622 PMid:22754260 PMCid:3385223

18. Jain PS, Patel MK, Gorle AP, Chaudhari AJ, Surana SJ. Stabilityindicating method for simultaneous estimation of olmesartanmedoxomile, amlodipine besylate and hydrochlorothiazide by RP-HPLC in tablet dosage form. J Chromatogr Sci 2012; 50(8): 680-7. http://dx.doi.org/10.1093/chromsci/bms067 PMid:22593253

19. Alsarra IA. High-performance liquid chromatographic method for quantitative determination of amlodipine in human plasma and pharmaceutical dosage form and its application to pharmacokinetic studies. J Chromatogr Sci 2009; 47(10): 863-7. http://dx.doi.org/ 10.1093/chromsci/47.10.863 PMid:19930795

20. Meyyanathan SN, Rajan S, Muralidharan S, Birajdar AS, Suresh B. A Validated RP-HPLC Method for Simultaneous Estimation of Nebivolol and Hydrochlorothiazide in Tablets. Indian J Pharm Sci 2008; 70(5): 687-9. http://dx.doi.org/10.4103/0250-474X.45420 PMid:21394278 PMCid:3038306

21. Shah DA, Bhatt KK, Mehta RS, Baldania SL, Gandhi TR. Stability Indicating RP-HPLC Estimation of Nebivolol Hydrochloride in Pharmaceutical Formulations. Indian J Pharm Sci 2008; 70(5): 591-5. http://dx.doi.org/10.4103/0250-474X.45396

PMid:21394254 PMCid:3038282

22. Spanakis M, Niopas I. Determination of atenolol in human plasma by HPLC with fluorescence detection: validation and application in a pharmacokinetic study. J Chromatogr Sci 2013;51(2):128-32. http:// dx.doi.org/10.1093/chromsci/bms116 PMid:22729617

23. Baheti KG, Shah N, Shaikh S. Ion-pairing reverse-phase high performance liquid chromatography method for simultaneous estimation of atenolol and indapamide in bulk and combined dosage form. Indian $\mathrm{J}$ Pharm Sci 2012; 74(3): 271-4. http://dx.doi.org/10.4103/0250474X.106076 PMid:23439934 PMCid:3574541

24. Seshadri RK, Desai MM, Raghavaraju TV, Krishnan D, Rao DV, Chakravarthy IE. Simultaneous quantitative determination of metoprolol, atorvastatin and ramiprilin capsules by a validated stabilityindicating RP-UPLC method. Sci Pharm 2010; 78(4): 821-34. http:// dx.doi.org/10.3797/scipharm. 1004-14 PMid:21179318 PMCid:3007609

25. Kallem RR, Mullangi R, Hotha KK, Ravindranath L, Spoorthy Y, Seshagirirao J. Simultaneous estimation of amlodipine and atenolol in human plasma: a sensitive LC-MS/MS method validation and its application to a clinical PK study. Bioanalysis 2013; 5(7): 827-37. http://dx.doi.org/10.4155/bio.13.39 PMid:23534427

26. Zou Q, Zhan Y, Ge Z, Wei P, Ouyang P. Liquid chromatography-mass spectrometry method for the determination of amlodipine in human plasma and its application in a bioequivalence study. Arzneimittel for schung 2009; 59(8): 383-91.

27. ICH, Q2B, Harmonized Tripartite Guideline, Validation of Analytical Procedure: Methodology, IFPMA, in: Proceedings of the International Conference on Harmonization, Geneva; 1996.

Cite this article as:

Panchumarthy Ravisankar, Garikapati Devala Rao. Isocratic separation of four beta blockers with Amlodipine by $\mathrm{C}_{18}$ RP-HPLC: Application to Amlodipine determination in pharmaceutical dosage forms. Int. Res. J. Pharm. 2013; 4(6):88-96 